\title{
Perils of Production: Farm Hazards, Family Farming, and the Mechanization of the Corn Belt, 1940-1980
}

\section{DEREK ODEN}

AFTER WORLD WAR II, Iowa farmers rapidly adopted new technologies, acquiring gasoline-powered machines and a new repertoire of chemicals and grain-handling equipment. "These physical manifestations of technological change," according to historian J. L. Anderson, "were signs that Iowa, the heart of the Corn Belt, was an industrial landscape as much as it was a rural one." 1 A "leading state in feed grain and livestock production," Iowa was also one the most cultivated states in the entire nation

1. J. L. Anderson, Industrializing the Corn Belt: Agriculture, Technology and Environment, 1945-1972 (DeKalb, IL, 2009), 5-6, 194. Other scholars investigating twentieth-century agriculture have used similar terms to describe how farmers' acquisition of new technologies transformed rural landscapes. In 1962 historian Wayne Rasmussen used the term second revolution to depict recent dramatic technological and economic changes. Wayne D. Rasmussen, "The Impact of Technological Change on American Agriculture, 1862-1962," Journal of Economic History 22 (1962), 578-91. Later John L. Shover made similar observations, indicating that rapid innovation had "turned traditional farming upside down." John L. Shover, First Majority-Last Minority: The Transforming of Rural Life in America (DeKalb, IL, 1976), 5. More recently, historians such as Deborah Fitzgerald and Stephen Stoll have incorporated the term industrial and associated terms to depict such change. Deborah Fitzgerald, Every Farm a Factory: The Industrial Ideal in American Agriculture (New Haven, CT, 2003), 3-5; Stephen Stoll, The Fruits of National Advantage: Making the Industrial Countryside in California (Berkeley, CA, 1998), 2.

THE ANNALS OF IOWA 73 (Summer 2014). (C) The State Historical Society of Iowa, 2014. 
and continued to be dominated by "family farming" throughout the period. ${ }^{2}$ The state's importance in agricultural production and the dominance of family farms make it ideal for a study investigating the work-related hazards of Corn Belt agriculture.

Anderson argued that Iowa farmers were the primary decision makers as they specialized to meet the demands of the marketplace by streamlining their methods and adopting new technologies. As a result, farm operators increasingly relied on monoculture and capital-intensive technologies to boost production. ${ }^{3}$ Americans living through and participating in these changes were fully aware of this transformation. In 1941 a rural journalist in Illinois wrote, "Some farmers believe that this is fast developing into a machine age in farming and that within a few years horses will be little used on farms and some places not at all." In 1966 Professors Walter R. Butcher and Norman K. Whittlesey of the University of Washington, speaking at a meeting of the American Farm Economics Association, stated, "Farming in the near future is likely to have more in common with today's factories than with many of today's farms." And in 1974 Iowa state legislator Michael Blouin complained that U.S. Secretary of Agriculture Earl Butz's farm policies favored "the industrialization of farming and the creation of an assembly line system of food production in this country." 4 As these statements indicate, the farm was becoming as much an outdoor factory as an organic process consisting of sun, soil, muscle power, and manure. Although scholars have investigated the multifaceted nature of these changes, the issue of safety in Corn Belt agriculture has been largely ignored.

2. Anderson, Industrializing the Corn Belt, 5-6. Shover also emphasized how farmers were increasing the scale of their operations. Nonetheless, farms during the era were overwhelmingly owned by individuals. As a result, family farming dominated Corn Belt agricultural production. For a detailed discussion of such economic and demographic issues, see Shover, First Majority-Last Minority, 164.

3. Anderson, Industrializing the Corn Belt, 190-96; Stoll, The Fruits of National Advantage, 16-24.

4. "Threshing Runs in Galt and Como Are through for Year," Sterling Daily Gazette, 8/11/1941; Ovid Martin, "University Economists Predict Million Dollar Farms for Agriculture," Muscatine Journal, 8/26/1966; "Blouin Says Butz Should Be Replaced," Cedar Rapids Gazette, 9/13/1974. 
Scholars who specialized in workplace safety and farm safety experts who labored to reduce accidents during the era agreed that farming was one of the nation's most dangerous professions from 1940 to 1980 . Some argued that the switch from horse-powered farming to petroleum-powered machines increased farm-related hazards. In 1983 Frederick R. Schneider, a retired Farm Security Administration official, said that, although "specific data" were not available for the early 1940s, he believed that "there was a noticeable increase in the number of farm accidents," particularly those involving machinery. Mark Aldrich, an expert on the history of industrial safety, recently concluded, "Manufacturing risks almost certainly declined more than risks in most sectors, at least after the mid-1920s, while agriculture may have become increasingly dangerous as it mechanized." 5 There is little statistical data about farm accidents for the period prior to World War II, so comparisons over time are problematic, but enough accident studies are available for the mid-twentieth century to support the argument that agriculture was a particularly hazardous profession. ${ }^{6}$

5. Frederick Schneider, "Tractor and Farm Machinery Safety," in Iowa Farm Safety in the 20th Century: A History of Contributions by Rural Safety Volunteers, ed. Herb Plambeck (Des Moines, 1983), 32; Mark Aldrich, Safety First: Technology, Labor and Business in the Building of American Work Safety, 1870-1939 (Baltimore, 1997), 262. Allan B. Kline, president of the American Farm Bureau Federation, agreed that "the increased mechanization of the farm operations, plus the speed at which we operate, has vastly increased the hazards to which all farm people are exposed every day." "Agricultural Leaders Endorse Farm Safety Week's Objective," Farm Safety Review, July/August 1948, 3.

6. An abundance of studies support the view that farming was and is especially dangerous. For further discussion and analysis of farm accident statistics, see John D. Rush, Fatal Accidents in Farm Work: An Analysis of 12,141 Fatal Accidents from 1940-1945 in the United States (Washington, DC, 1949), 1-12; Conrad F. Fritch, Occupational and Non-Occupational Fatalities on U.S. Farms, Agricultural Economics Report 356 (Washington, DC, 1976), 2-9; Arnold B. Skromme, "A Farm Safety Program Sponsored by Farmers" (paper presented at the annual meeting of the American Society of Agricultural Engineers, Chicago, December 18-21, 1990), 1-3. These studies and others rank farming among the nation's most hazardous occupations. Nonprofit organizations and governmental agencies such as the Occupational Safety and Health Administration and the National Safety Council have produced a variety of documents confirming agriculture's persistently high ranking. Such documents can be accessed by consulting online resources at www.osha.gov and www.nsc.org. For a discussion of how farm safety activists created a vibrant educational movement in response to the farm safety problem, see Derek Oden, "Selling Safety: The Farm Safety Movement's Emergence and Evolution from 1940-1975," Agricultural History 79 (2005), 412-38. 
In 1988 Purdue University agricultural engineers Mark A. Purschwitz and William E. Field noted that agriculture had ranked first or second in the category of "most dangerous industry in the U.S." every year since 1979 and in the top three for more than 30 years. The perception that farm accidents were increasing convinced many agricultural leaders that something needed to be done. Still, as Purchwitz and Field argued, despite agriculture's hazardous nature, the federal government devoted paltry funds to preventing accidents. ${ }^{7}$

Before examining the specific mechanical hazards that farm families encountered, it is crucial to recognize the unique nature of agricultural labor as well as the dominant forms of farm machinery. First, farm work differed from labor in sectors such as textiles, steel, and food-processing industries. The typical factory worker was an employee who worked indoors, often as part of a system of mass production. Farmers, however, operated a business that existed in a familial setting characterized by a dependence on child labor in which training was disseminated primarily from parent to child. Farm hazards were also dramatically influenced by the structural differences between agriculture and other occupations associated with industrial processes. Farmers were generally independent, and agriculture was less consolidated than manufacturing. This relatively autonomous status meant that regulations were generally adopted more slowly than in other industries. Farm families were not only responsible for the proper maintenance and safe operation of their equipment but also were more exposed to the economic consequences of accidents. They had less access to benefits such as workers' compensation than factory workers who were often employees of large corporations. Additionally, farmers worked outdoors in all seasons, in isolated rural settings, alongside both animals and machines, all of which complicated and diversified potential hazards. ${ }^{8}$

7. Mark A. Purschwitz and William E. Field, "Safety Spending: Is Agriculture Being Shortchanged?" Agricultural Engineering 69, no. 7 (November/December, 1988), 10.

8. A wealth of literature on the development of twentieth-century factory and manufacturing labor provides a useful contrast with farm work. See, for example, Lindy Biggs, The Rational Factory: Architecture, Technology, and Work in America's Age of Mass Production (Baltimore, 1996), 224; David A. Hounshell, From the American System to Mass Production, 1800-1932 (Baltimore, 1984), 411; and Robert 
In sum, Corn Belt farmers worked in a unique, highly industrialized setting in which the home and workplace intersected. As a result, farm life during the period was hazardous for the entire family.

FARMERS adopted a variety of technologies to increase crop production in response to a diverse array of economic factors, including changing government policies, escalating production expenditures, and shrinking profit margins. Anderson describes this overpowering trend as a "cost price squeeze," which, he argues, was crucial in a farmer's decision to mechanize rapidly. ${ }^{9}$ In the 1950s Iowa farmers faced growing capital needs. In 1957 Herbert Crock from Olin complained, "Land is high but so is everything else." Clifton Klaus of Colesburg noted one of the implications: "For a young fellow starting out the investment in stock and machinery is too high." Don Rimathe and Craig Fausch, both lifelong farmers in Story County, expressed similar sentiments. Rimathe vividly portrayed the ever-growing scale, costs, and sophistication of farming as a "vicious circle." Fausch echoed his friend's comments that farmers were constantly "spreading the costs out." Farmers also experienced increasing labor expenses, which appears to have accelerated the trend toward mechanization. ${ }^{10}$

Farmers purchased tractors, harvesting equipment, grain transport devices, and hay processing machinery at a dramatic rate. From 1940 to 1950 the number of tractors on farms rose from 1.6 million to 3.4 million, signaling the decline of the horse and

Kanigel, The One Best Way: Frederick Winslow Taylor and the Enigma of Efficiency (New York, 1997), 675. Scholars have devoted much less attention to examining farmers' unique working conditions. For an investigation of these conditions and how they relate to the issue of safety, see Derek Oden, "Harvest of Hazards: The Farm Safety Movement, 1940-1975" (Ph.D. diss., Iowa State University, 2006).

9. Anderson, Industrializing the Corn Belt, 193.

10. "The Farmer's Opinion," Cedar Rapids Gazette, 7/21/1957; Don Rimathe, interview by author, 1/3/2013; Craig Fausch, interview by author, 1/3/2013. Midwestern newspapers identified an intensifying shortage of workers. See, for example, Arthur Bystrom, "Wisconsin Farmers Swelled Production Hard Way," Rhinelander [WI] Daily News, 3/7/1945; and "Farm Hiring Clinic at Fort Dodge Wednesday, Jan. 25," Humboldt Independent, 1/17/1956. See also Anderson, Industrializing the Corn Belt, 120. 
mule as a power source. ${ }^{11}$ By the 1950s, the oddity of using horses on the farm had become newsworthy. In 1956 the Racine Journal Times reported that Tom Ballack, a Wisconsin farmer who still depended on horses to plow and cultivate his fields, was "perhaps the only farmer in Racine County who uses horses regularly for farm work." 12

Farmers also rapidly acquired mechanical corn pickers. Between 1941 and 1951, the number of corn pickers farmers were using grew from approximately 120,000 to 502,000 . The majority of these machines could be found in midwestern states such as Iowa, Illinois, and Indiana. By 1951, Iowa farmers had procured 95,000 corn pickers, the most in the nation, followed by their counterparts in Indiana and Illinois who had purchased 48,000 and 80,000 machines respectively. The introduction of the combine corn-head resulted in a similarly rapid adoption by farmers who sought greater ease and efficiency in the corn harvest. The number of elevators also "doubled on the average every two years" from 1940 to 1959, reaching one million on the nation's farms by 1959.13

Farmers' acquisition of agricultural equipment not only led to more efficient production but also to increasing physical risks. The Iowa Cooperative Extension Service conducted a study of fatal farm accidents in the period from 1947 to 1971 that placed the agricultural accident problem in context. A grisly sum of 1,773 individuals had died in machinery-related farm accidents during the period. The investigators concluded that the dramatically expanded use of farm equipment had amplified the hazards associated with agricultural machinery. They also believed that while mechanization had contributed to a reduced work load and

11. Don Paarlberg and Phillip Paarlberg, The Agricultural Revolution of the Twentieth Century (Ames, 2000), 24.

12. O. C. Hulett, "For 86 Years Ballacks Have Used Horses to Farm Their 240 Acres," Racine [WI] Journal Times, 5/6/1956. For more on the decline of horsepowered farming, see F. A. Hankins, "Word from the Country: Hankins Would Like More Horse Stories," Cedar Rapids Gazette, 7/21/1963.

13. Charles Scranton, "Safety and the Mechanical Corn Picker," Agricultural Engineering 33, no. 3 (March 1952), 140; Benson J. Lamp and Kenneth A. Harkness, "Recommendations for Improved Design of Portable Elevators" (paper presented at the annual meeting of the American Society of Agricultural Engineers, Chicago, December 15-18, 1959), 1. 
an exodus from the farm, it also meant that the remaining farmers worked in a more mechanically sophisticated environment. ${ }^{14}$

Farmers readily acknowledged the dangers associated with farm work. Jim Klein, who grew up on a northern Iowa farm near Ashton in the 1960s and 1970s, commented that "at least a dozen times I should have been killed on the farm." Larry Glenn, a lifelong Iowa farmer in Wapello County, agreed that one had to be careful around "everything." Lawrence Schmitz recalled that his father "warned him daily" about the many hazards associated with agricultural life. ${ }^{15}$

Thus, researchers and farmers agreed that farming presented a host of hazardous situations that could result in serious bodily harm or even death. A farmer could be trapped under a tractor as a result of a rollover. A child could be caught in a power takeoff or fall and be crushed underneath a tractor's wheel. During the harvesting of grain, agricultural laborers needed to be aware of a corn picker's swiftly moving parts. Processing square bales of hay was also hazardous: a hand or foot could get caught in the machinery. Large round bales of hay could easily tip over a tractor. Farmers also adopted new material handling devices such as elevators and augers; their moving parts presented dangers, and elevators could tip over if improperly transported. Farmers who procured grain bins needed to be aware of dangerous gases that could damage lungs or cause asphyxiation. The diversity of hazards distinguished farming from other occupations such as factory work, which often emphasized specialization or mastery of more concentrated skills.

14. Iowa State University Cooperative Extension Service, Fatal Accidents of Iowa Farm People, 1947-1971 (Ames, 1971), 8-9. Researchers also provided yearly snapshots of the farm accident problem in the Midwest. Wallaces' Farmer reported that "farm accidents claimed 467 Iowa lives" in 1952 alone. "Gear Your Farm for Safe Living," Wallaces' Farmer and Iowa Homestead, 7/19/1952, 10. In 1957 an Ohio farm accident researcher found that at least 58 Ohioans had been killed in tractor accidents in the previous year in that midwestern state. Wilbur Stuckey and William Gill, "Tractor Tragedy," Farm Safety Review 15, no. 9 (November/December 1957), 13.

15. Jim Klein, interview by author, 12/15/2012; Larry Glenn, interview by author, 12/28/2012; Lawrence Schmitz, interview by author, 12/28/2012. 
THE VULNERABILITY of farm residents was exacerbated by the fact that the farmstead functioned as both a home and a workplace. Home and workplace were usually clearly delineated for town dwellers but intersected for farm families. Furthermore, children worked and played on farms even as their environments were becoming more technologically sophisticated. As a result, farm families encountered a dizzying array of hazards that affected rural individuals regardless of age. Leroy Hogeland, a lifelong farmer from Monroe County, began doing chores "as soon as my hands were big enough to hold a hoe." Teresa Klein, summarizing the farm safety problem vividly while recalling her childhood on a dairy farm near Oelwein in the 1960s and 1970s, stated, "People don't ever think of having their kids live at the factory with them, but that's essentially what you're doing; you're living on a very dangerous factory." 16 Klein's comments vividly capture how farm families were exposed to hazards in ways that were unique and pervasive.

Children's natural inexperience and curiosity combined with the complexity of agricultural machinery to pose special problems. Lawrence Schmitz, a farmer from Wapello County, related a story from the late 1940s when, as he and his friend were headed home on their tractors "out of sight of both dads," they kicked their tractors out of gear and raced down a big hill. He stressed that such races were unsafe but that such potentially dangerous playfulness was not unusual for farm boys. Bernard Stodghill, another career farmer from Wapello County, stated that he once broke his arm trying to start the family's F12 International tractor. He acknowledged that the accident was the result of improper technique in starting the tractor, but he had desperately wanted to help his dad. Perry Middlesworth, another lifelong farmer

16. Leroy Hogeland, interview by author, 1/3/2013; Teresa Klein, interview by author, 12/15/2012. Farm children were particularly vulnerable because the few legal safeguards that existed applied only to individuals who worked as farm employees and did not protect the thousands of children who worked on their own families' farms. Thus, parents were ultimately responsible for their children's welfare and for assigning them age-appropriate work tasks. For further insights regarding labor laws and farm dangers associated with farm children, see U.S. Department of Labor, Employment Standards Administration, Wage and Labor Division, Child Labor Requirements in Agriculture under the Fair Labor Standards Act, Child Labor Bulletin No. 105 (Washington, DC, 1984), 1-5; and Harold Heldreth, "Safety for Farm Children," Farm Safety Review, March/ April 1955, 12. 
from Wapello County, echoed his neighbor's observations, commenting that once when he was 10 years old, while driving his father's Minneapolis Moline UB, he "ran the harrow right into the fence and took the wing clear off of it." 17 Such incidents powerfully demonstrate how youths sometimes took unnecessary risks or were inadequately trained for a particular job.

Farmers' entrepreneurial status also distinguished their occupation from others such as those in manufacturing or extractive industries such as coal mines. Some farmers viewed this feature of their chosen career as beneficial because it enabled greater flexibility and freedom than other professions. John Van Ringelstein of Wapello County said that being his own boss was an advantage of the agricultural lifestyle. Prospective farmers made similar comments regarding the independence derived from the farming way of life. In 1950 Dwight Colliver, a 17-year-old Future Farmers of America member from Sigourney, said that his interest in farming was largely related to how it was a "good occupation and you are your own boss." In 1966 Plymouth County farmer Larry A. Peterson concurred: "I wanted to farm so that I would be working for myself." This independent spirit persisted and was widespread. Jim Klein believed that many of his friends wanted to be farmers so they could also be "their own boss." 18

SUCH AUTONOMY expressed itself in at least a skeptical but sometimes even a hostile view of safety regulations. Farmers expressed this resistance to outside influence in their workplace in response to the events following the passage of the Occupational Safety and Health Act of 1970. The Occupational Safety and Health Administration (OSHA) actually had minimal impact on family farmers during the 1970s, yet many of them expressed their displeasure with the agency's threat to their autonomy. ${ }^{19}$ In 1976

17. Lawrence Schmitz interview; Bernard Stodghill, interview by author, 12/29/2012; Perry Middlesworth, interview by author, 12/29/2012.

18. John Van Ringelstein, interview by author, 12/28/2012; “The Farmer's Opinion," Cedar Rapids Gazette, 4/20/1950; Bill Tudor, "Outstanding Farmer Works for Future Successes," Le Mars Daily Sentinel, 3/22/1966; Jim Klein interview.

19. For a useful general discussion of the early history of the Occupational Safety and Health Administration, see Charles Noble, Liberalism at Work: The Rise and Fall of OSHA (Philadelphia, 1986). For a description of the nature of 
the editors of IH Farm Forum, a periodical sponsored by the International Harvester Company, asked their readers' opinions of OSHA. The results reflected only the opinions of the 829 Farm Forum subscribers who returned the feedback form, but it nonetheless indicated that farmers generally held an unfavorable view of the agency. The survey confirmed that most of the respondents believed that OSHA officials were largely incompetent and that they were wrongly interfering with farmers' work. The piece also exposed a common attitude that farm safety, like many domains of farmers' work, was familial in nature. Lloyd Ziegler, an Illinois farmer, expressed the commonly held belief that it was appropriate for adolescent boys to operate tractors: "I've trained three sons to operate tractors, and I started each one of them at 12. First, they learned to operate the tractor with no equipment attached. Then I let them operate the tractor with light loads for an hour or two at a time until they were ready to do bigger jobs. Any showing off and they were grounded." Ziegler also represented a majority of the respondents who did not appreciate what they viewed as OSHA's misguided attempt to prevent accidents. ${ }^{20}$

Some farmers were even more direct in expressing their resistance to what they believed to be OSHA's capacity to threaten their independence. In 1974 a proposal that would have required farmers to "retrofit" older equipment with safety features such as shielding caused a visceral reaction. Harold V. Cobbs, a farmer from Lodi, Wisconsin, summed up his feelings: "We will never submit to young, long-haired college kids from the Department of Labor inspecting our farms and slapping us with fines that could put us out of business." 21 In 1976 the rural public's reaction

OSHA regulatory activities in one midwestern state and the controversy the agency engendered amongst Iowa's agricultural leaders, see Plambeck, ed., Iowa Farm Safety in the 20th Century, 143-48.

20. "Reporting Back: On Farm Safety and OSHA," IH Farm Forum 1 (Fall 1976), 26-29. In response to the question "Should OSHA or OSHA type regulations be extended to include the farmer and members of his family as well," 88 percent of the respondents chose either "No, a farmer's safety should be his own responsibility and no law is going to make him more safe" or "Under no circumstances does the government have any business telling a farmer whether to practice safety." Ibid.

21. "Farmers Object Vigorously to Proposed Safety Devices," Sheboygan [WI] Press, 8/27/1974. For a brief but insightful summary of a public hearing regard- 
to a pamphlet titled Safety with Beef Cattle, published by OSHA, was particularly harsh. Some felt that the brochure lacked substance and reflected a condescending tone. Lyle Borg, a member of the Iowa Farm Bureau Federation, said, "Bureaucrats: we are not a group of helpless children. We are educated professionals operating the most involved, respected, and important industry in the world." 22 John Dvorak, a writer for the Kansas City Times, surmised that Missouri and Kansas farmers viewed OSHA's involvement in agriculture to be "less popular with farmers than a weed-infested cornfield." C. R. Johnson, a farmer near Springfield, Missouri, who was also the president of the Missouri Farm Bureau, staunchly resisted OSHA intervention. Johnson expressed a common sentiment: "There are just things that government can't do." 23 These farmers' reactions to OSHA's potential involvement suggest the relevance of considering the value they placed on their independence and autonomy when examining the issue of farm safety.

FARMERS' INDEPENDENCE influenced other aspects of their work more directly than a distrust of regulation did. For instance, a farmer's success depended on individual effort and the seasonal aspect of the work. Because farmers sometimes handled large amounts of capital, their choices could also have a dramatic impact on their financial survival. Story County farmer Don Rimathe stressed the need to work long hours during harvest time: "If you miss that window, you might miss out for a long, long time and end up with a lousy crop." Pat Larkin, a career farmer from Wapello County, emphasized the profession's fiscal pressures: "I never minded hard work, but I hate the stress, you know, handling so much money today." "One little mistake,"

ing proposed OSHA machine guard standards, see "OSHA in Agriculture: Machinery Guarding Hearing," Implement and Tractor, 10/7/1974, 56-58, which reports a number of controversies regarding OSHA standards, including the prohibitive cost of retrofitting older equipment with new safety features such as machine guards.

22. Mary Ovrom, "OSHA Has Some Zingers," Burlington Hawk Eye, 8/8/1976.

23. James Dvorak, "Farmers Not Too Receptive to Increased OSHA Impact," Lawrence [KS] Journal-World, 9/29/1977. 
he added, can have profound financial consequences. Jim Klein remembered that after his father retired from farming he was finally able to get a full night's sleep. As Illinois farmer Joe Slaymaker observed, such burdens could affect safety, for one could be preoccupied more with working quickly than carefully. Many farmers, he noted, are "thinking about something else. Get that job done-it's going to rain-hurry-pressure, pressure, pressure." James Wilson, a lifelong farmer from Appanoose County, added that farming was particularly stressful during harvest time. He remembered falling asleep several times while harvesting crops late into the night, which presented obvious risks. ${ }^{24}$

Such work-related stress and excessively long work days exposed farmers to heightened risks. In 1946 a Farm Safety Review writer recognized this tendency, highlighting farmers' decreased alertness since they were exposed to the "hazards of this occupation for longer periods than most workers." Robert Westpfahl, an Illinois farmer, commented that some farmers "just run these machines into the ground and there is no machine safer than the man running it. If a man has been running the machine for 16 or 18 hours a day for seven days a week, he is getting dangerous." John Van Ringelstein emphasized the seasonal stresses of farming. There were times, he recalled, that "you'd work like the dickens on days you had to get the crop in, and there were times, rainy days, you could take off." 25 Such comments reflected the unique aspects of farming compared to manufacturing jobs with more established work schedules and a predictable indoor environment. They also suggest that while farmers' independence offered an unusual level of freedom, it also exposed them to work-related risks that would have been less common in more consolidated industries.

24. Don Rimathe interview; Pat Larkin, interview by author, 12/29/2012; Jim Klein interview; Joe Slaymaker, "One Farmer's View of Safety" (speech given at the National Institute of Farm Safety meeting in Rock Island, Illinois, June 17, 1981), Norval Wardle Collection, Iowa State University Archives, Iowa State University, Ames; James Wilson, interview by author, 12/30/2012.

25. Arthur W. Turner, "Let's Be Sensible about Farm Safety," Farm Safety Review, November/December 1946, 9; Robert Westpfahl, "Another Farmer's View of Safety" (speech given at the National Institute of Farm Safety meeting in Rock Island, Illinois, June 17, 1981), Norval Wardle Collection; John Van Ringelstein interview. 
Farming's cyclical demands were not the only aspects of Corn Belt agriculture that could extend working hours. Many farmers maintained their agricultural responsibilities while holding a second job. Bernard Stodghill was a lifelong farmer who at the same time held a full-time job at Anderson Erickson Dairy in Des Moines. His dual work responsibilities were not unusual, especially for farmers who owned or rented small acreages. In 1969 D. B. Pointer, a farm editor for the Jefferson City Post Tribune, noted that "the high cost of living, increased taxes, and a dwindling market price for farm products in relation to land and equipment costs, has caused a stampede of small farmers seeking a job in the city to supplement farm income." It is difficult to know the degree to which the resulting stress contributed to accidents; however, in the early 1960s Stodghill sustained a horrible injury after a shift at the dairy. He caught his hand in a tractor-mounted corn picker and had to drive himself to a neighbor's house for emergency assistance. Although he recovered, Stodghill's loss of part of a finger served as a permanent reminder of his accident. ${ }^{26}$

FARMERS not only faced considerable time-related stresses, but their rapid procurement of equipment also meant that they had to adapt swiftly to the introduction of new machinery, which could also add to work-related risks because farmers were largely responsible for their own training. The rapid acquisition of gasoline tractors provides a case study of this challenge. Some farmers who lived through this transitional era found it challenging, especially those who previously had used horses. Robert Westpfahl, reflecting on the difficult transition his family had experienced going from horse-powered machinery to tractorpowered implements, stated that farmers of an earlier era "had been walking behind horses for 40 years and all of a sudden they give him this machine, and he knew that before all he had to do

26. Bernard Stodghill interview; D. B. Pointer, "Part-Time Farming Way of Life," Jefferson City [MO] Post Tribune, 4/10/1969, 15. The issue of part-time farmers appeared occasionally in midwestern newspapers throughout the era. See, for example, W. D. Davison, "Country Squire Faces Challenges," Waterloo Sunday Courier, 1/20/1960; and Rodney Hayden, "Part-time Farming Costly," The Advocate [Newark, OH], 9/10/1975. 
was tell the horse to stop and the machine stopped wherever he was working. Well, after he got the tractor, he would stop the tractor, but sometimes the machine wouldn't stop. Well, that is just plain suicide because those guys have never been around a machine and mechanical things." Lawrence Schmitz made similar comments regarding his observations of a hired hand who awkwardly made the transition from horses to tractors in the 1940s. Years later Schmitz recalled, "He'd get on that tractor; he'd never driven one before, so it was comical to watch him try to get going. It was almost like you had to get down there and lead him." 27

Sometimes this uneasy shift could contribute to unsafe situations. In 1952 a Wallaces' Farmer author wrote, "Some farmers drive tractors the same way they drove horses. The horses did part of the thinking for the driver. Tractors don't think for you. It doesn't make any difference to a tractor whether it plows up the corn or the weeds." Robert Westpfahl reflected on his grandfather's experience when making the transition from horses to tractors: "One time when he was out harrowing with a tractor, the harrow came unhooked from the tractor and he didn't know it came unhooked until he drove it completely around the field and ran over it the next time. And that is the truth. He was to me one of the smartest and most intelligent men that I have ever met. I mean I really respected him. But he never grew up with anything that was behind him or running around him. He had always been around a horse." 28

Some farmers who came of age in the early twentieth century were uncomfortable with the switch to power farming. Don Rimathe, who was born in 1945, vividly described his grandfather's attitude to the new technology. "Horses were probably second nature to him," he recalled, but "he did not like things with engines; he loved horses." Larry Glenn's father also was not a "lover of tractors and machinery." Leroy Hogeland, born in 1932, provided the perspective of a younger generation of farmers who, unlike some in an older cohort, welcomed the change. "If I had to have been a horseman," he observed, "I would have had to have been something else; I would not have been a farmer. I was never

27. Westpfahl, “Another Farmer's View,” 1; Lawrence Schmitz interview.

28. “Gear Your Farm for Safe Living," 10; Westpfahl, “Another Farmer's View," 1. 
a horse lover that much. I had some really, pretty bad experiences, like biting. Dad was kicked, thrown off of horses." 29 These observations demonstrate an important point: comfort levels with technological innovation were often age-related. But for farmers of all ages, mechanical innovations were transforming farm work and presenting new challenges.

The diversity of farm equipment posed challenges because indepth knowledge was required to properly operate and maintain each machine. Farmers were usually not experts on any individual piece of equipment and did not work in close proximity to machinists, mechanics, or engineers who did have mechanical expertise. Instead, they were generalists who operated different kinds of equipment while completing their daily chores. Some writers emphasized that farmers existed in a more mechanically diverse environment than more specialized occupations. Craig Fausch, who spent decades working in agriculture, echoed these conclusions: "You do a lot of different things in a day's time." Modern farming thus took place in a complex, challenging environment. ${ }^{30}$

The challenges presented by workplace diversity were exacerbated by the general lack of formal training opportunities. In 1942 Frank Zink, the director of the Farm Equipment Institute's Research Department, pondered, "Who trains the operator of a machine? Who trains the new or young operator of a farm machine? The probable answers to these two questions are-the older persons, either fathers or farm hands, neither class of which may have had any safety training." 31 Thus, unlike workers in a manufacturing setting, farmers usually relied on family members to learn how to operate machinery, often at very early ages. Craig Fausch recalled spending many hours as a second rider on his dad's tractor. He was with his father every day and "lived and breathed" farming from an early age. As Don Rimathe observed,

29. Don Rimathe interview; Larry Glenn interview; Leroy Hogeland interview.

30. "Practice Safety with Machinery," Hoard's Dairyman, 8/10/1943, 466; "Farm Accidents Are Made," Hoard's Dairyman, 7/20/1943, 412; Craig Fausch interview. 31. Frank J. Zink, "Farm Equipment Can Be Operated Safely" (paper presented at the Nebraska Conference on Home and Farm Safety, Lincoln, Nebraska, October 2,1942), 5. Zink also observed that the war had only exacerbated the problem as millions of inexperienced laborers entered the agricultural workforce with insufficient training, particularly large numbers of women and children who were replacing males serving in the armed services. Ibid., 6 . 
"You can learn about the science of farming, but to learn how to do the job-I just don't think you can learn it without being there." 32 As farmers learned to farm from their fathers at an early age, they were likewise exposed to the hazards of farming from an early age.

Farmers were also responsible for maintaining their equipment to ensure that it operated efficiently and safely. John Van Ringelstein remembered his father in the late 1930s working hard in cold weather to start their 1020 McCormick-Deering tractor. He would "build a fire underneath it to make the grease warm enough so they could shift gears." Perry Middlesworth reflected that maintenance changed as innovations continually altered the equipment. He noted that back in the 1960s "everything had to be greased every day," but by the 1980s he had learned that overgreasing sealed bearings was unwise and might cause expensive machinery repairs. ${ }^{33} \mathrm{New}$ equipment posed challenges to farmers who not only adopted many types of new machines over the years but who also had to be aware of new features and maintenance requirements to avoid costly repairs and prevent accidents. Thus, as farming knowledge became more intricate, farmers were forced to adapt to rapidly advancing innovations.

FARMERS also had to adjust to the rapidly increasing speed of moving parts, which were often inadequately protected. The power take-off (PTO) was particularly dangerous. The whirling device, which contributed significantly to agricultural efficiency by transferring energy from a tractor to many types of agricultural equipment, was a leading agent in farm accidents. Farmers could be injured by a PTO by accidentally falling on the whirling shaft, hastily stepping over it, or wearing loose clothing that could become entangled. All of these practices could end in serious injury or even death. Removing the PTO guard multiplied the hazards. In 1950 E. W. Tanquary, who chaired the Farm Equipment Institute's Advisory Engineering Committee, stressed the importance of using such shields. "The best designed and most expensive shield ever provided is worthless if left in the implement

32. Craig Fausch interview; Don Rimathe interview.

33. John Van Ringelstein interview; Perry Middlesworth interview. 
shed and the implement operated without it," he noted, "yet accidents are reported where ample shields were provided with the implement and left off through carelessness." 34 Machines that reduced physical drudgery also increased the speed of farming, producing unintended and unexpected consequences. Farmers' decision making also affected the probability of suffering an accident.

Many farmers recognized the potential of a swirling PTO shaft to result in death or injury. Appanoose County farmer Rex Peterson was keenly aware of farm hazards since his father lost his arm in a corn picker accident in the 1940s. When he witnessed his son stepping over a PTO shaft, it had "scared him to death." Seeing his son's unwise action so upset him that he broke the handle of a corn rake that he was holding. Perry Middlesworth remembered being extra careful around the PTO shaft as a result of seeing a sack become entangled in the whirling shaft: "It caught a burlap bag once, and in no time it was wrapped around it tight." After seeing that bag, he was "a lot more safety oriented." 35 Middleworth's comments are especially important because they show that, unlike workers in other work environments, farmers often learned about safety experientially and arbitrarily.

The corn picker relieved farmers of the physically demanding task of hand harvesting, but its rapidly moving parts could catch limbs and appendages. Agricultural engineer Charles Scranton celebrated the fact that "these pickers have ended the backbreaking and time-consuming job of hand harvesting, and the day of the horse and wagon in corn picking is pretty well on the way out." Nonetheless, he acknowledged that "with the growth in the number of mechanical pickers has come an unwholesome record of farm accidents." Lee Thompson, writing in Wallaces' Farmer, considered the corn picker to be one of the most potentially hazardous pieces of agricultural equipment. Such assessments were amplified by gruesome stories that included disturbing accounts of farmers who were forced to cut through their own fingers or arm to free themselves from a corn picker. Leroy Hogeland, who often purchased used equipment at farm sales, stated that sometimes

34. E. W. Tanquary, "Safe Guarding Power Driven Farm Machinery" (paper prepared for the Farm Equipment Institute's Advisory Engineering Committee, Chicago, Illinois, 1950), Norval Wardle Collection.

35. Rex Peterson, interview by author, 1/1/2013; Perry Middlesworth interview. 
"you'd go to a farm sale and you'd see a guy with just one hand and you didn't have to ask him what had happened; you knew." 36

Researchers who studied the corn picker situation confirmed Hogeland's bleak observation and identified contributing factors. Agricultural engineer Charles Scranton identified 434 corn picker accidents in 1948 in Iowa, the state with more corn pickers than any other state. In 1951 Norval Wardle, an Iowa State University farm safety specialist, systematically investigated 418 corn picker accidents in the state. He believed that the accidents could be attributed to such factors as operator fatigue, employing careless work practices, and not using safety shields. The parts most responsible for corn picker accidents were, in order, "husker rolls, snapper rolls, chains, elevators, and stalk ejectors." Such fastmoving, unguarded machinery parts could produce devastating consequences if a hand or arm found itself in their path. As Rex Peterson stated simply and ominously, "Machinery is made to grab stuff" and thus one had to exercise great caution around it. ${ }^{37}$

Farmers were particularly vulnerable if, while rushing to complete the harvest, they attempted to unclog a picker or make repairs with the power still on. In 1952 the wife of a Wapello County farmer commented on this aspect of the problem: "I think that the men just try to get in a hurry when they are tired." An exhausted farmer could get caught in the picker's rollers or chains in a variety of ways. In 1955 Daniel Kitchen stated, "Many accident victims have dismounted with the power take-off running with no intention of approaching the picker. Then they saw an ear crossway in the elevator, saw a stalk of corn laying across the picker points - or they stumbled or lost balance. And another hand was added to the list." Regardless of the situation, Kitchen reinforced the idea that farmers could prevent many accidents by turning off machines before trying to fix them. John Van Ringelstein avoided accidents with an early combine corn head by using an old broom handle to unclog it. He remembered

36. Tanquary, "Safe Guarding Power Driven Farm Machinery," 140; Lee Thompson, "Haste Costs Arms," Wallaces' Farmer and Iowa Homestead, 10/6/1951, 5; C. L. Hamilton, "Live to Pick Another Year," Wallaces' Farmer and Iowa Homestead, September/October 1948, 4; Leroy Hogeland interview.

37. Scranton, "Safety and the Mechanical Corn Picker," 140; Franklin, "Don't Lose an Arm," 8; Rex Peterson interview. 
that by the day's end the handle was chewed up to the point that it was very short. 38 Although Ringelstein's practice reflects farm ingenuity, it also embodies the common theme that farmers often faced hazards alone, armed only with their own resourcefulness.

Haymaking tasks became easier as the result of mechanical advances such as new mowers, rakes, and baling equipment; but new dangers surfaced at the same time. During the 1940s the safety literature described a plethora of injuries that could ensue during haymaking, including cuts from mowers, crushing injuries from rakes, as well as the possibility of entanglement in the baler's moving parts. James Wilson provided a chilling account of a near fatal experience with a round baler in 1967. He remembered, "I always felt like I was 4 or 5 seconds away from losing my life. I got my foot caught in an Allis Chalmers Round Baler and the tractor was running wide open." He surmised that if a hired man hadn't been present, the outcome might have been very different. Wilson's experience highlights the fact that farmers faced particular risks due to their solitary occupation, which often meant that they did not receive prompt emergency treatment. ${ }^{39}$

As haymaking continued to advance with equipment improvements such as the big round baler, accidents continued to occur. The production of big round bales eased the burdensome task of handling the much smaller round and square bales but presented its own set of risks. Transporting the large bales proved dangerous. By the mid-1970s, such devices produced hay bales as large as 1,000 to 1,500 pounds. Sam Brungardt, an Implement and Tractor contributor, noted that farmers sometimes unwisely adapted older front-end loaders to move large round bales. Unfortunately, the heavy bales could cause tractors to capsize

38. "Pick More Corn-Safely," Farm Safety Review, September/October 1958, 8-9; Franklin, "Don't Lose an Arm," 8; Daniel Kitchen, "Stop That Picker . . . Before You Leave the Tractor Seat," Farm Safety Review, September 1955, 5; John Van Ringelstein interview.

39. James Wilson interview. Bernard Stodghill's corn picker accident in 1964 also illustrates this point. He drove his tractor and mounted picker home in order to receive emergency assistance. Bernard Stodghill interview. Iowa's newspaper record also contains examples of farmers whose medical treatment was delayed because of their isolated work environment. See, for example, "Goodin Loses Hand in Picker Accident," Elgin Echo, 11/5/1953; and "William De Wall Breaks Leg in Silo Accident," Titonka Topic, 3/15/1956. 


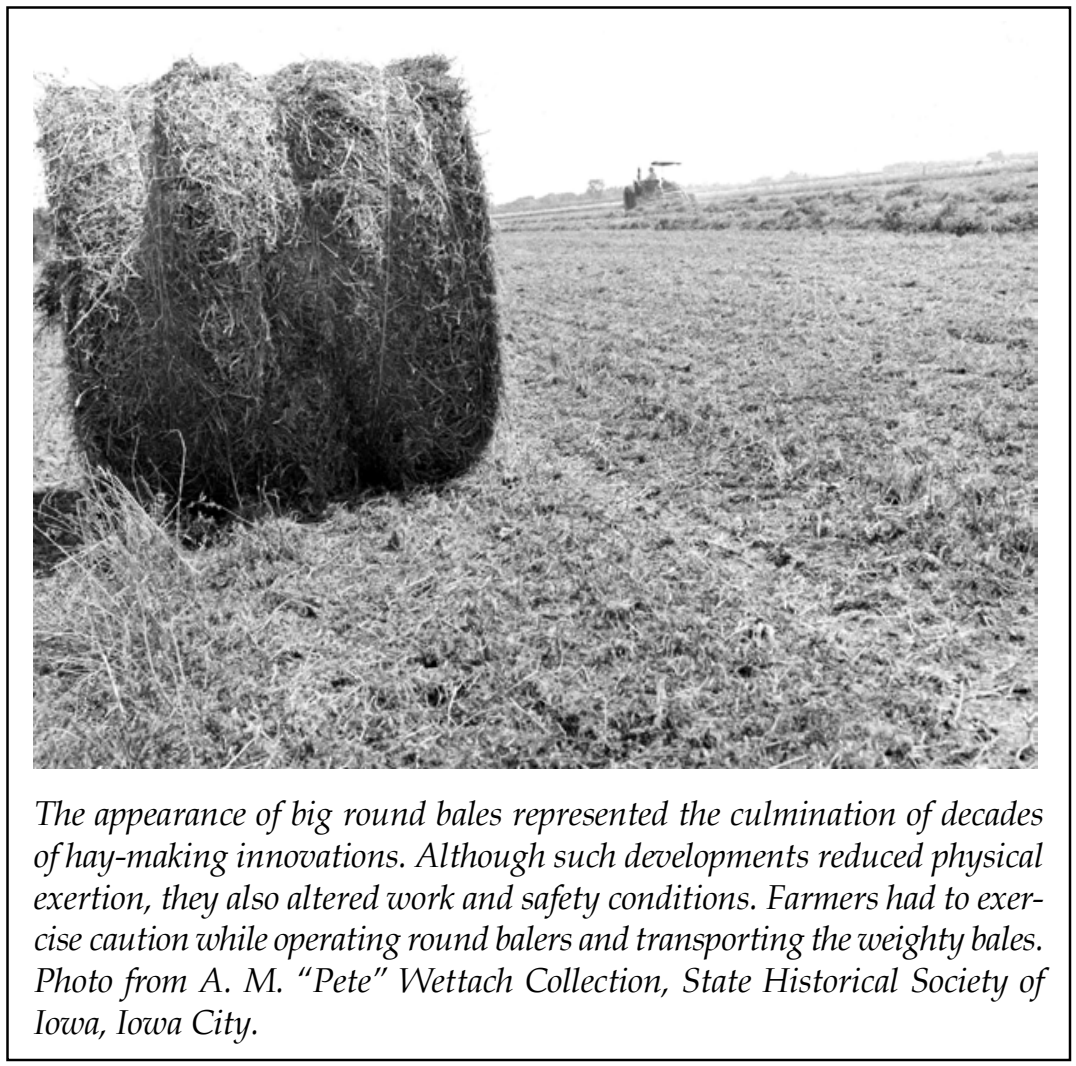

and crush farmers underneath their machines. ${ }^{40}$ The slow implementation of safety features exposed farmers and their families not only to the dangers associated with unguarded moving parts but also to crushing injuries due to the lack of tractor cabs.

Farmers faced this danger for decades as many continued to use tractors that were not fitted with roll-over protective technology long after that technology had been introduced. In A pril 1952 Marion County farmer Paul Murphy experienced a frightful incident when his tractor overturned on a hill. Fortunately, he was able to leap off quickly and escape without injury. "No doubt about it," Murphy said, "I was lucky. I have always tried to be careful with a tractor, but this accident really scared me." Larry

40. Sam Brungardt, "Safe Handling of Big Bales," Implement and Tractor, March 1976, 12. 
Glenn did not own a tractor with a cab until the mid-1960s, and many farmers he knew didn't have them until much later. At first, Glenn appreciated the shelter from inclement weather more than the added safety protection. Jim Klein's family had several tractors, and they continued to use one without a cab until his dad retired from farming. This economically practical but potentially dangerous practice of using older equipment that lacked safety features was prevalent for decades. ${ }^{41}$

EVEN IF farm implement companies produced safer machinery, farmers would not necessarily purchase it. One such example involves the safer transport of hay bales. Dr. Richard L. Jepsen, a farm safety specialist from Kansas State University, believed that even though "three-point-hitch bale handling devices" were safer than "modified front-end loaders," farmers would persist in using less stable adapted front-end loaders. Rollin Schnieder, a University of Nebraska farm safety expert, echoed Jepsen's opinions: "Some of the front-end loaders which are modified in farm shops may be poorly engineered and put excess stress on a tractor's hydraulic system." 42

Sometimes, however, farmers did make a rapid transition to safer equipment. Such was the case in the changes associated with the corn harvest. The introduction of the combine corn-head increased both the speed and safety of harvesting because it gathered corn more quickly and clogged less often than a corn picker. In the mid-1960s an Implement and Tractor contributor praised

41. "Next Time . . . This Might be You!" Wallaces' Farmer and Iowa Homestead, 6/7/1952, 8; Larry Glenn interview; Jim Klein interview. Agricultural engineers and safety specialists produced an exhaustive literature on the tractor rollover protection structure (ROPS) and the advantages of using it to prevent fatalities. See J. R. Myers and K. A. Snyder, "Roll-over Protective Structure Use and the Cost of Retrofitting Tractors in the United States, 1993," Journal of Agricultural Safety and Health 1 (June 1995), 185. According to David H. Bucher, a high-ranking engineer for John Deere, "Tractor upsets cause 50 to 70 percent of the fatal farm accidents in this country." David H. Bucher, "A Protective Canopy for the Farm Tractor," Agricultural Engineering 48 (September 1967), 496. For more on how tractor overturns were a leading cause of deaths on the nation's farms and the need to implement ROPS devices, see Ernest C. Carlson, "Frame the Operator for Safety's Sake," Excavating Contractor 56 (October 1968), 12.

42. "Next Time... This Might be You!" 13. 
the continued improvement of the machines, which had "more horsepower, larger grain tanks, more efficient drives, more hydraulic applications, larger fuel tanks, more diesel engines, bigger elevators and unloading augers, improved operator platforms, and larger headers - they are bigger and better than ever." New safety features augmented the performance improvements. In 1965 a National Safety Council staff writer opined that a number of modifications, including better shielding over moving parts and headers that congested less frequently while harvesting corn more quickly, had made harvesting safer. The improved shielding did not go unnoticed by farmers. Rex Peterson indicated that guarding had improved to the point that today "everything is so protected you can't hardly service them." Don Rimathe agreed that guarding had improved dramatically in recent decades. ${ }^{43}$

Farmers could also suffer serious injury or even death while using augers and elevators. In the late 1950s and early 1960s David McFarland and William Fletcher emphasized the dangers associated with being hurt when such devices overturned. Such incidents occurred for a variety of reasons, including simply losing control during transportation or unintentionally upending the device while attempting to clear debris from the elevator's trough. The prospect of accidentally running into another object represented a common hazard. According to McFarland and Fletcher, "the accidental hitting of the undercarriage by a tractor or other object can quickly topple an elevator which has been set on sloping terrain." Farmers further exposed themselves to serious injury if they attempted to stop a falling elevator. All of these situations could result in becoming pinned under the machine, causing serious injury or death. Perry Middlesworth remembered once as a boy that he thought he was "strong enough to lift up an elevator," which came down on him and pinned him to the ground, leaving a gash in his knee. ${ }^{44} \mathrm{~A}$ boy's overly enthusiastic desire to help his father could result in serious threats to a youth's well-being.

43. Mark Zimmerman, "Scanning the Self-Propelled Combines," Implement and Tractor, 6/21/1965, 20; T. David McFarland, "Eight Steps to Combine Safety," Farm Safety Review, May/June 1965, 3-4; Rex Peterson interview; Don Rimathe interview.

44. W. E. Stuckey, B. J. Lamp and K. A. Harkness, The Portable Farm Elevator .. . Make it a Helper Only, Bulletin 367 (Columbus, OH, 1962), 2-3 (this is a revised 


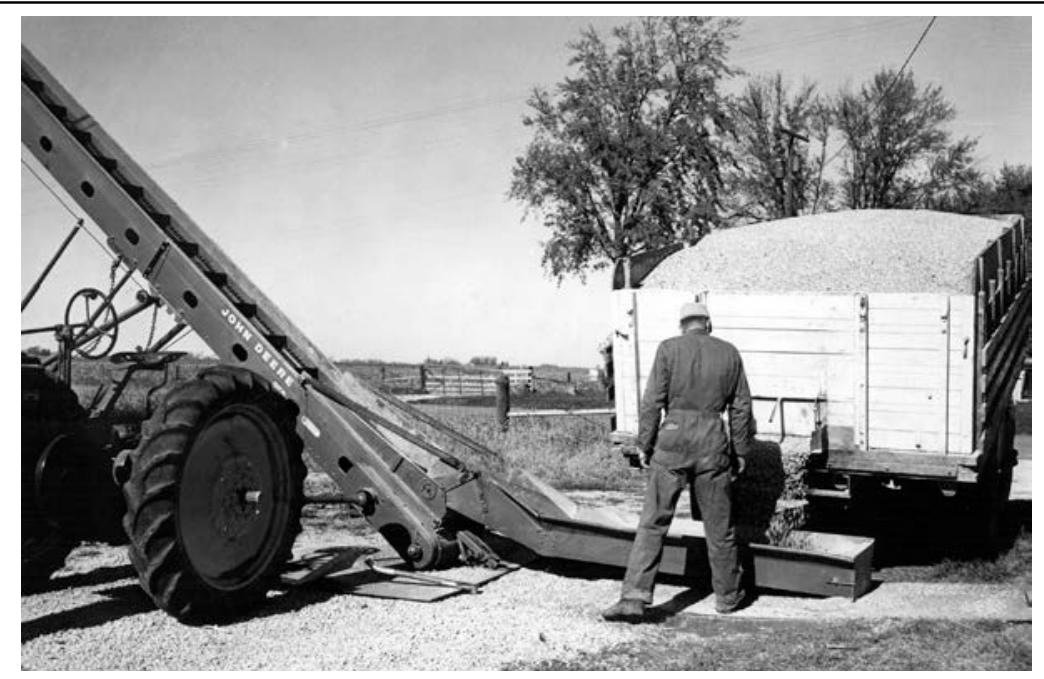

Grain elevators eased the arduous task of shoveling grain by hand. Unfortunately, farmers were sometimes caught in whirling PTO shafts or other rapidly moving of parts of such devices. Photo from A. M. "Pete" Wettach Collection, State Historical Society of Iowa, Iowa City.

Besides their desire to be helpful, children's natural curiosity and playfulness could also lead to accidents with elevators. Ohio farm safety specialists documented serious injuries and deaths in such elevator accidents. Two boys had fallen to their deaths from an elevator. One had been running up an elevator when he stumbled, plummeted to the ground, and died; the other youth, who had climbed up an elevator hoping to enter a barn's hay mow, also fell to his death. In 1973 B. J. S. Grogono, a surgeon from Halifax, Nova Scotia, described a gruesome aspect of auger accidents involving children. When a child's limb became caught in an

version of a 1957 Ohio State publication regarding elevator precautions: W. E. Stuckey and B. J. Stamp, Live Longer with Portable Elevators, Bulletin 367 [Columbus, $\mathrm{OH}, 1957], 5,8)$; Perry Middlesworth interview. In the face of such accident problems, engineers were making progress by adding features such as "safety tracks" to elevators, which provided stability; nevertheless, such accident prevention devices were not on all new models in the late sixties. For more on the issue of elevator safety, see Stuckey, Lamp, and Harkness, The Portable Farm Elevator, 4; and T. David McFarland and William J. Fletcher, Analysis of Portable Farm Elevator and Auger Accidents to Determine Corrective Measures (Washington, DC, 1969), 33-34. 
auger, the damage could be greater than for an adult because a child's extremities were smaller. Thus, their arms and legs were pulled farther into the machine and suffered more damage. ${ }^{45}$

By the late 1960s, researchers agreed that such incidents involving entangled limbs represented the most persistent elevator hazard for both children and adults. The problem was exacerbated because manufacturers were slow to install shields on the elevator's moving parts. Some experts believed that the failure to provide guards might have been related to the perception that an elevator's moving parts moved more slowly than those of other farm equipment. However, "contact with an unshielded power shaft rotating at slow speeds definitely is a hazard and can result in severe accidents, as elevator accident reports verify. There is no justification for elevators to be manufactured and sold without properly shielded shafts and gears." 46 Thus, agricultural safety experts and engineers were still grappling with tremendous changes even as farmers struggled to adapt to an increasingly sophisticated mechanical environment.

The lack of guards on augers persisted into the late 1960s. In 1969 "an informal survey of machines on dealers' lots, at agricultural shows, and in sales literature ... measure[d] the 'state of machine' guarding on U.S. machines." The survey found that "most V-belt drives were unshielded, even on machines of recent vintage. Auger intake guarding varied from none to the provision of several rods running parallel to the auger shaft at the base end. Most PTO shafts on new machines are shielded, but on many units, the stub shaft shield where the shaft connects to the elevator is in need of improvement." In 1972 a review of a number of manufacturing brochures revealed that augurs were on the whole insufficiently guarded and that the lack of protection presented a significant threat to farm families. The expert who conducted the review charged that the companies that produced such machines thus displayed a lack of concern for safety. He illustrated his point by disclosing that some farmers had crafted guards themselves following accidents. For example, Horace Neu,

45. Stuckey and Stamp, Live Longer with Portable Elevators, 7; B. J. S. Grogono, "Auger Injuries," British Journal of Accident Surgery 4, no. 3 (February 1973), 243. 46. Lamp and Harkness, "Recommendations for Improved Design of Portable Farm Elevators," 3. 


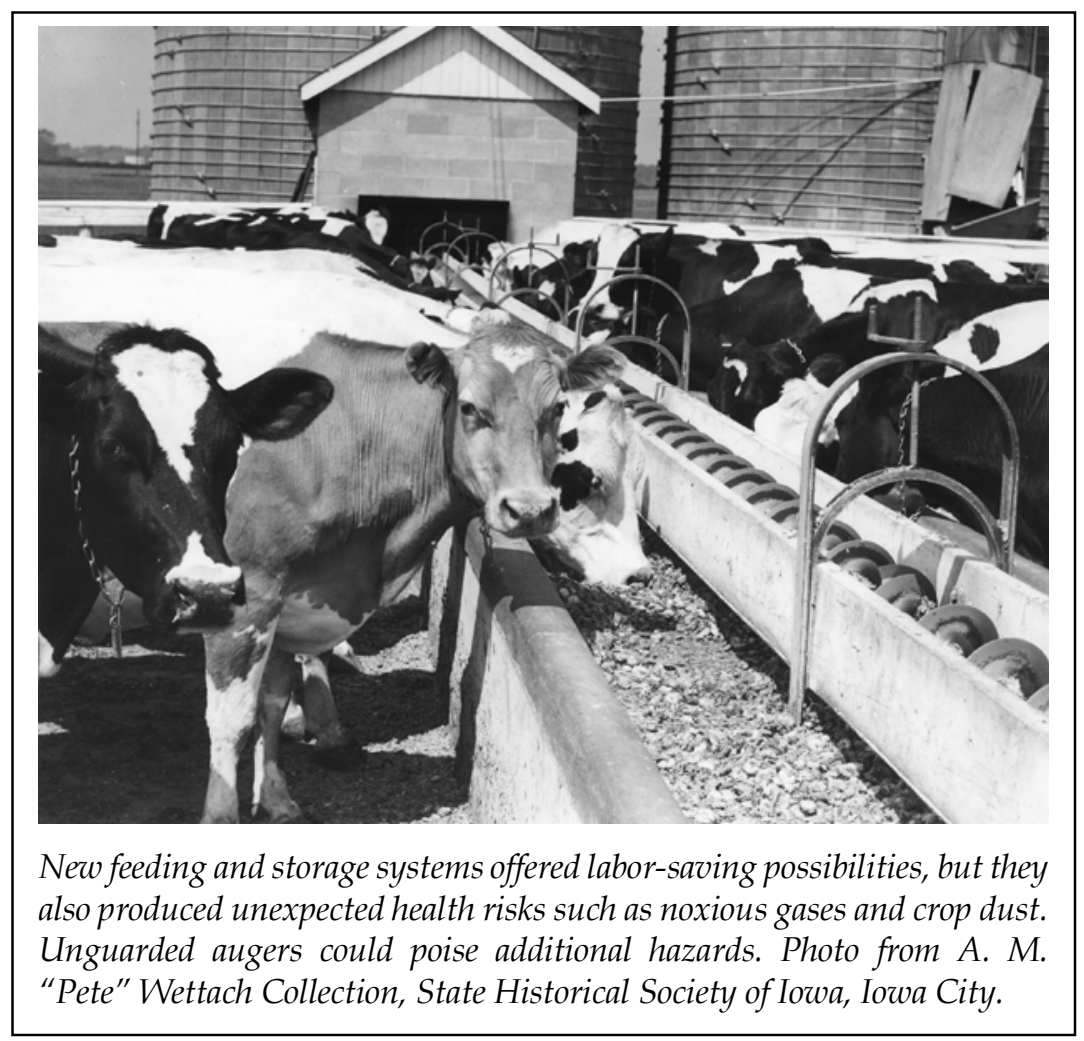

a farmer from Nevada, Iowa, had fashioned a "lattice type guard over the auger's intake" after catching his hand in an auger. ${ }^{47}$

To address the complicated, rapid, and multifaceted consequences of agricultural technology, farmers adopted other technologies that probably reduced accidents or at least saved wear and tear on their bodies. For instance, the advent of "self-feeding silos" may have lessened the dangers associated with feeding livestock by automating much of the process. Earl D. Merrill, an official for Republic Steel Corporation, stated that farmers now could avoid the potentially dangerous practice of "climbing conventional silo chutes and lugging silage to feed bunks." He

47. McFarland and Fletcher, Analysis of Portable Farm Elevator and Auger Accidents, 33; Norval Wardle, "Safety Controls and Shielding for Augers" (paper presented at the annual meeting of the American Society of Agricultural Engineers, Hot Springs, AR, June 28, 1972), 3-4. 
claimed that researchers had been searching for ways to decrease the work associated with feeding livestock their silage. "Mechanical unloaders in the top or bottom of silos looked promising, but they did not deliver the silage to livestock. Silo structural and management adjustments to permit the animals to feed directly from the silos now seem to offer the most promising solution." 48

Pat Larkin, a lifelong beef cattle producer from Wapello County, emphasized the importance of improvements in livestock-handling systems, stressing that such developments were crucial in lessening the hazards associated with working with cattle. Larkin worked for ten years at the Iowa State University Extension Service helping researchers improve livestock structures. He stated, "I got into designing a lot of facilities for working cattle and we designed it to where you never got in a pen with the cattle. ... We used to grab a calf and throw him down and vaccinate him, but now we drive him up an alley way, reach through, and poke him with the use of a head gate." Larkin underscored that such structures, which emerged not only from practical experience but also from animal behavior research, reduced hazards for people and lessened animal stress while increasing cattle-processing speed. ${ }^{49}$

Additional innovations reduced farmers' exposure to bullrelated hazards. By the mid-1950s, when some farmers no longer required a bull's reproductive services, scientists had discovered new solutions to bull hazards. In 1956 Harold Heldreth observed that farmers' growing interest in artificial insemination and the possibility that this reproductive method would enjoy increasing popularity might mean that fewer farmers needed bulls. "Besides eliminating a serious farm accident hazard and the expense of keeping individual bulls," he noted, "the plan also extends or multiplies the services from valuable bulls many fold." 50

In addition to reducing exposure to livestock hazards, technological improvements also reduced health risks in other ways. For instance, the increased use of the round baler undoubtedly

48. Earl D. Merrill, "Self-Feeding Silos Aid Safety," Farm Safety Review, March/ April 1953, 3.

49. Pat Larkin interview.

50. Harold E. Heldreth, "Safe Practices Can Mean Bigger Profits," Farm Safety Review, August 1956, 9. 
reduced the physical exertion associated with handling hay bales. Previously, while catching hay bales and stacking them in the hay mow, John Van Ringelstein noted, "a sixty-pound bale of hay would frequently hit me in the head." 51 Fortunately, the reduction in work associated with the mechanization of hay harvesting and storing reduced physical wear and tear.

HORSE-POWERED AGRICULTURE of an earlier era had not been without risks. For example, in Kansas more than 90 people had been killed in runaway horse accidents between 1930 and 1945. Twenty people died in horse-related mishaps in Wisconsin in 1944. ${ }^{22}$ Even though the number of horses was decreasing, rural families continued to use them into the 1950s. In 1955 Harold Heldreth commented on this dual, multigenerational use: "Thousands of farm people-boys, girls and adults - are in the saddle daily, carrying out farm jobs that can be done more efficiently on a mount. Many farm people also seek recreation in the saddle." 53

The dangers remained in Amish communities that continued to rely on horse-powered farming. In the mid-1990s, Amish families in LaGrange County, Indiana, suffered a sudden increase of horse-related accidents that killed six of their members. Purdue University faculty sought to help families address this spike in horse-related fatalities. Scott Whitman, a Purdue University farm safety expert, searched through the university's collections for obsolete horse safety handbooks. Whitman stated, "We might have to dust them off and see if we can use them again." Although machines undoubtedly changed agricultural working conditions, farming had always been fraught with danger and uncertainty. ${ }^{54}$

51. John Van Ringelstein interview.

52. Marvin J. Nichol, “How's Your Horse Sense?," Farm Safety Review, May/June 1945,8 . Horse accidents were nothing new and likely even more common when farmers depended on horses to plow, disc, and harvest their fields. For stories of horse accidents in the midwestern rural press, see, for example, "Right Leg Amputated; Another Farm Accident," Aberdeen [SD] American, 5/4/1915; and "Badly Injured in Farm Accident," Grand Forks [ND] Herald, 5/21/1915.

53. Harold E. Heldreth, "Safe in the Saddle," Farm Safety Review, January/February 1955,5 .

54. "Amish Seek Help in Cutting Down Farm Accidents," Cedar Rapids Gazette, 5/26/1996. 
The most basic tool involved in hay processing, the pitchfork, could inflict severe damage if used unwisely. A pitchfork user could become injured in many ways, and such injuries were often ghastly. In 1943 Claire Swisher, editor of the Hammermill Bond, indicated that although pitchforks were indispensable for farm work, they were sometimes involved in fatal accidents. Their sharp points could easily puncture the flesh and even organs, and some farmers had fallen off their hayracks and impaled themselves on their pitchforks. Such accidents usually resulted in grotesque deaths. In 1943 a Farm Safety Review writer stated that Mr. Hedge, a farmer from Leavenworth, Kansas, "climbed onto the hay loft, threw food down for the cattle, and tossed the fork into it. As he started down the ladder, he missed the top rung. The additional impact broke the second rung and he fell. The fork handle pierced deeply into his abdomen, and he died a few days later." 55 Such gruesome stories served as vivid reminders of the dangers of agricultural labor.

Safety writers provided abundant advice about how to avoid pitchfork accidents. Their suggestions included owning several of them and locating them in convenient places, thus limiting the need to carry them. They also advised that under no circumstances should a pitchfork be tossed, and it should always be placed firmly in the earth instead of placing it flat on the ground. ${ }^{56}$ Larry Glenn remembered an uncle telling him a pitchfork accident story involving a youth who was impaled as he played while others were putting up loose hay. ${ }^{57}$ The story left a powerful impression regarding the hazards associated with farm work. It also demonstrates that farming presented significant hazards long before farmers acquired the sophisticated machines of the mid-twentieth century.

55. Claire Swisher, "An Editor Talks about Pitchforks," Farm Safety Review, September/October 1943, 7. The Hammermill Bond, of which Claire Swisher was the editor, was published exclusively for the employees of the Hammermill Paper Company. "Pitch Forks Are Dangerous," Farm Safety Review, November/December 1945, 9.

56. "Pitch Forks Are Dangerous," 10.

57. Larry Glenn interview. 
THE STORY of Corn Belt farm dangers reveals that farmers encountered more immediate and sometimes deadly costs beyond those associated with increasing expenses of land, machines, and labor. That price can be counted in the fingers lost to corn pickers, or in the lives of young children snuffed out by the terrible weight of an overturned tractor. The frightful toll was also represented in the fact that farming ranked as one of the most dangerous professions during each of the decades from 1940 to 1980. Agricultural equipment hazards were amplified by farm families' diverse working environment, their comparative independence, and the rapid rate of technological change. Farmers also often felt pressured to get their work done quickly due to ever-changing weather and economic conditions. The lack of safety features such as adequate guarding and tractor roll bars amplified the dangers. Thus, even though the phenomenon of astonishing agricultural productivity owed much to mechanical improvements, mishaps with these machines sometimes produced a harvest of injury and death.

The agricultural safety issue was also influenced by the view of farming as both a way of life and an industrialized business. The former view can be found in a variety of sources, including sentimental reminiscences of rural childhood, as well as in surveys from the era. A study conducted by University of Missouri researchers in 1967 revealed this deeply personal attachment: "A farmer doesn't decide to farm in the same way that a mechanic or salesman chooses his work. To a farmer, farming is a way of life, not just a job." James Wilson echoed these comments when explaining his decision to return to farming after returning home from military service during the Korean War. He said that once you've farmed, "it never leaves you." 58 Despite such warm sentiments, most Corn Belt farmers could not ignore the inescapable fact that agriculture's industrialization had produced a variety of unintended and unpleasant consequences.

Nevertheless, many farmers still highly valued their independence and communicated a cautionary attitude toward stringent safety regulations, an attitude that was clearly demonstrated

58. "Farming Is Way of Life unlike Most Other Jobs," Jefferson City [MO] Daily Capital News, 11/17/1967; “Winter Increases Peril of PTO's for Farmers," Mason City Globe Gazette, 1/14/1966; James Wilson interview. 
by many farmers' resistance to OSHA regulations in the mid1970s. James Wilson echoed this sentiment when he stated, "We are pretty dang independent and if some city slicker comes out and tells us how to do something, we're just going to walk off and leave him." 59 Although Wilson's comments communicate an important rationale for choosing a farming lifestyle, the farm accident story suggests that such independence was becoming more difficult to maintain. Farmers' continued acquisition of new equipment reflected the ongoing process of replacing an earlier reliance on muscle power with a dependence on machines and fossil fuels. Although these powerful tools freed them from the back-breaking tasks of hand-picking corn, processing loose hay, and transporting grain, it exposed them to a plethora of new hazards, many of which they did not fully comprehend. Farmers lessened their chance of injury or death by working slowly, using guards, and avoiding working by themselves. They could also reduce dangers to their children by giving them age-appropriate work. Even if such measures were followed, however, the combination of work autonomy with the technologically advanced nature of modern agriculture could still prove to be a lethal combination.

The unique aspects of farming meant that working safely at all times would have been difficult. Farming remained familial, less consolidated, and offered fewer formal training opportunities than other industries that were also undergoing industrial change. In addition, the growing technological complexity of farming produced an environment in which hazards were not only diverse and numerous, but also not immediately apparent. Farmers adopted new equipment, chemicals, and storage practices rapidly in an effort to remain economically competitive. Any hope of a complete understanding of such hazards would have been as unfeasible as would have fully adopting all safe work practices in a timely manner. James Wilson reflected this dilemma while discussing his experience working in metal grain bins and breathing crop dust. He stated, "I would come out of there coughing and spitting with black stuff coming out of my nose. You just thought it was all right. You're trying to make a

59. James Wilson interview. 
living and get ahead." 60 His comment communicates the reality that economic pressures could sometimes trump safe work practices even if one knew the proper safety procedures.

Despite the profound changes that accompanied this era, some features of farm life, such as a sense of community, remained. Neighbors often responded to accidents affecting their neighbors with compassion by doing much-needed work. In 1959 a story in the Muscatine Journal and News-Tribune showcased how a community responded to the situation of Guy Hoobler and Floyd Hausman, both of whom had been injured in farm accidents. The paper reported that "two separate crews are being organized to harvest corn crops for the injured men." The Postville Herald reported another community's response to a corn-picker accident: "A large group of neighbors, friends and relatives came to the Harold Hoffman farm home Saturday with corn pickers and a wagon and helped husk about 60 acres of corn." 61

The power of community could sometimes mitigate the effects of dramatic technological change, yet the toll of farm accidents remained significant. Rex Peterson, reflecting on the corn-picker accident in which his dad lost his arm, stated, "It affected the whole family. It had an awful impact on dad." 62 Farm families paid an incalculable physical, emotional, and psychological price as they produced abundance for the food needs of an ever expanding global population.

60. Ibid. For a fascinating and influential perspective on risk and its meaning in the late twentieth century, see Ulrich Beck, Risk Society: Towards a New Modernity, trans. Mark Ritter (London, 1992). Beck's observation that during the twentieth century threats to human welfare transitioned from more organic factors to those created by an increasingly technologically sophisticated society is particularly germane to an investigation of the health risks associated with Corn Belt agriculture, since by the mid-twentieth century, agricultural technologies and economic dangers had greatly altered the hazards associated with farming. 61. "Neighbors to Husk Corn at Morning Sun," Muscatine Journal and NewsTribune, 11/10/1959; "Good Neighbors Help at Hoffmans," Postville Herald, 11/25/1959. For similar stories elsewhere in the Iowa press, see "Pick Corn for Bud Weis," Harlan News-Advertiser, 11/20/1951; "Friends Make Hay for Sumner Farmer," Waterloo Daily Courier, 7/8/1962; "35 Acres, 41 Good Neighbors," The Guthrian [Guthrie Center, IA], 6/23/1969.

62. Rex Peterson interview. 